\title{
Sub-Picosecond Laser Deposition of Thin Films
}

\author{
F. Génin, B. Stuart, W. McLean, L. Chase
}

November 3, 2000 


\section{DISCLAIMER}

This document was prepared as an account of work sponsored by an agency of the United States Government. Neither the United States Government nor the University of California nor any of their employees, makes any warranty, express or implied, or assumes any legal liability or responsibility for the accuracy, completeness, or usefulness of any information, apparatus, product, or process disclosed, or represents that its use would not infringe privately owned rights. Reference herein to any specific commercial product, process, or service by trade name, trademark, manufacturer, or otherwise, does not necessarily constitute or imply its endorsement, recommendation, or favoring by the United States Government or the University of California. The views and opinions of authors expressed herein do not necessarily state or reflect those of the United States Government or the University of California, and shall not be used for advertising or product endorsement purposes.

This work was performed under the auspices of the U.S. Department of Energy by the University of California, Lawrence Livermore National Laboratory under Contract No. W-7405-Eng-48.

This report has been reproduced directly from the best available copy.

Available electronically at http://www.doc.gov/bridge

Available for a processing fee to U.S. Department of Energy

And its contractors in paper from

U.S. Department of Energy

Office of Scientific and Technical Information

P.O. Box 62

Oak Ridge, TN 37831-0062

Telephone: (865) 576-8401

Facsimile: (865) 576-5728

E-mail: reports@adonis.osti.gov

Available for the sale to the public from

U.S. Department of Commerce

National Technical Information Service 5285 Port Royal Road

Springfield, VA 22161

Telephone: (800) 553-6847

Facsimile: (703) 605-6900

E-mail: orders@ntis.fedworld.gov

Online ordering: http://www.ntis.gov/ordering.htm

\section{OR}

Lawrence Livermore National Laboratory Technical Information Department's Digital Library

http://www.llnl.gov/tid/Library.html 


\title{
Sub-picosecond laser deposition of thin films
}

\author{
F. Génin, B. Stuart, W. McLean, L. Chase
}

The 1999 Nobel Prize in Chemistry recognized the importance and growing maturity of the femtosecond time-scale in science and engineering. Understanding the interaction between materials and high energy density light to manufacture and process materials has become a key issue in both programmatic and fundamental research at Lawrence Livermore National Laboratory. We have emphasized in this research the aspects related to producing thin films by ablation of material with intense ultra-short laser pulses.

Our effort during FY2000 has been focused on building the foundation of this research using high purity graphite as the initial ablation material. We have deposited diamond-like carbon (DLC) in vacuum, measured ablation rates, and characterized the physical and chemical properties of the films. We successfully completed our first objective to compare the microstructure and materials properties of the films deposited using lasers operated in the femtosecond and nanosecond pulselength regime. The mechanical characterization of the deposits showed improved film-substrate adhesion properties that allowed us to build $200-\mu \mathrm{m}$ thick layers using $150 \mathrm{fs}$ pulses. Films produced with ns-pulses delaminated as soon as the thickness reached only a couple of microns. The stresses in the films were greatly influenced by the fluence and the duration of the laser pulses. The microstructure and surface morphology of the films did not vary significantly with the processing parameters studied (pulse length and fluence). Finally, we demonstrated that it is possible to significantly increase the deposition rate with shorter pulses at a given fluence. In particular, carbon could be deposited at a rate of $25 \mu \mathrm{m} /$ hour with this technology.

Our goal in FY2001 is to study and model the relationship between the ablation plume characteristics (energy, charge, mass, and momentum) and the film growth behavior in order to influence and optimize the deposition process. We also want to determine if the laser parameters influence the stoichiometry of the deposits when compounds or alloys are used as ablation targets. We plan to investigate materials such as $\mathrm{TiC}, \mathrm{SiC}, \mathrm{AlN}$, and polymers for the study. 